\title{
Investigating the impact of human resource management practices on employee engagement, and the moderating role of strategy implementation in Egypt
}

\begin{tabular}{|c|c|}
\hline \multicolumn{2}{|c|}{$\begin{array}{l}\text { Authors: } \\
\text { Mohamed M. Saad } \\
\text { Hazem R. Gaber } \\
\text { Ashraf A. Labib } \\
1\end{array}$} \\
\hline \multicolumn{2}{|c|}{$\begin{array}{l}\text { Affiliations: } \\
{ }^{1} \text { College of Management and } \\
\text { Technology, Arab Academy } \\
\text { for Science, Technology and } \\
\text { Maritime Transport, } \\
\text { Alexandria, Egypt }\end{array}$} \\
\hline \multicolumn{2}{|c|}{$\begin{array}{l}\text { Corresponding author: } \\
\text { Mohamed Saad, } \\
\text { dr.mohamed.mostafa.saad@ } \\
\text { gmail.com }\end{array}$} \\
\hline \multicolumn{2}{|c|}{$\begin{array}{l}\text { Dates: } \\
\text { Received: } 08 \text { June } 2020 \\
\text { Accepted: } 09 \text { Mar. } 2021 \\
\text { Published: } 13 \text { May } 2021\end{array}$} \\
\hline \multicolumn{2}{|c|}{$\begin{array}{l}\text { How to cite this article: } \\
\text { Saad, M.M., Gaber, H.R., \& } \\
\text { Labib, A.A. (2021). } \\
\text { Investigating the impact of } \\
\text { human resource } \\
\text { management practices on } \\
\text { employee engagement, } \\
\text { and the moderating role } \\
\text { of strategy implementation in } \\
\text { Egypt. SA Journal of Human } \\
\text { Resource Management/ } \\
\text { SA Tydskrif vir } \\
\text { Menslikehulpbronbestuur, } \\
\text { 19(0), a1412. https://doi. } \\
\text { org/10.4102/sajhrm. } \\
\text { v19i0.1412 }\end{array}$} \\
\hline \multicolumn{2}{|c|}{$\begin{array}{l}\text { Copyright: } \\
\text { (c) 2021. The Authors. } \\
\text { Licensee: AOSIS. This work } \\
\text { is licensed under the } \\
\text { Creative Commons } \\
\text { Attribution License. }\end{array}$} \\
\hline \multicolumn{2}{|l|}{ Read onlin } \\
\hline 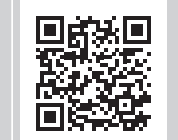 & $\begin{array}{l}\text { Scan this QR } \\
\text { code with your } \\
\text { smart phone or } \\
\text { mobile device } \\
\text { to read online. }\end{array}$ \\
\hline
\end{tabular}

Orientation: The concept of employee engagement has attracted the attention of both academics and practitioners due to its importance in enhancing the performance and profitability of organisations.

Research Purpose: This article examines the impact of human resource management (HRM) practices on employee engagement in the Egyptian context. The purpose of this article was to develop an in-depth understanding of the concepts of HRM practices and their impact on employee engagement, and the moderating role of strategy implementation.

Motivation for the study: Given the scarcity of research that examines the impact of HRM practices on employee engagement especially in the banking sector, this article examines how different HRM practices can influence the level of employee engagement.

Research approach/design and method: For the purpose of answering the research questions and testing the proposed hypotheses, a quantitative research approach was adopted by distributing a questionnaire to 228 employees from the banking sector in Egypt.

Main findings: The findings indicated that HRM practices had a positive significant impact on employee engagement. In particular, these practices included selection and hiring, job design as well as reward and payment systems. However, the findings showed that the strategic implementation does not moderate the relationship between HRM practices and employee engagement.

Practical/managerial implications: This article provides some guidelines for organisations to follow to fully utilise the power of employee engagement by applying effective HRM practices.

Contribution/value-add: The contribution of this study is that it is one of the few studies that have so far investigated this relationship in the Egyptian environment.

Keywords: human resource management practices; HRM practices; employee engagement; Egyptian context; developing countries.

\section{Introduction}

In today's competitive business environment, many organisations are looking for new ways to enhance the productivity and performance of their human resources (Przytuła, Strzelec, \& Krysińska-Kościańska, 2020).

Attracting, maintaining and developing an effective workforce is becoming one of the key challenges that these organisations are facing (Diaz-Carrion, López-Fernández, \& RomeroFernandez, 2021). In particular, after the outbreak of coronavirus disease 2019 (COVID-19) pandemic, many organisations across different business sectors have been eager to learn new ways of enhancing the efficiency and productivity of their operations (Przytuła et al., 2020).

One of the main concepts that has been rising in the recent organisational behaviour literature is the concept of 'employee engagement' (Sun \& Bunchapattanasakda, 2019). This concept is used to describe employees who are eager to play vital roles in enhancing the value creation processes of their organisations (Deeb et al., 2020). 
Engaged employees tend to put much effort and time for the purpose of enhancing the productivity and performance of the firms that they are working in (Sun \& Bunchapattanasakda, 2019). For these reasons, it is critical for organisations to search for new ways to make employee engaged in the workplace.

The extant literature proposes three dimensions of employee engagement. For instance, Shuck, Adelson and Reio (2017) argued that the concept of 'employee engagement' is used to describe employees who are cognitively, emotionally and behaviourally engaged in the workplace. Cognitive engagement (CE) refers to the degree to which employees are focused on their tasks, where they are mentally immersed and absorbed in performing their expected tasks (Joo, Zigarmi, Nimon, \& Shuck, 2017). On the other hand, emotional engagement (EE) refers to the degree of affection and devotion that employees have towards their tasks and organisations (Reina, Rogers, Peterson, Byron, \& Hom, 2018). Finally, the behavioural dimension refers to a group of actions that can be seen in employees' commitment to their tasks and their exertion of the highest effort possible for the benefit of their organisations (Shuck et al., 2017).

The purpose of this article is to examine the relationship between human resource management (HRM) practices and the three dimensions of employee engagement. The article focuses on five main HRM practices, which are the selection and hiring processes, training and development, job design, job security, and rewards and payment systems (Barrick, Thurgood, Smith, \& Courtright, 2015). This is considered important because the extant literature shows some shortcomings regarding the antecedents of employee engagement (Saks, 2019). Thus, our article fills this important research gap where there is scarcity of research that examines the impact of HRM practices on employee engagement, especially in developing countries like Egypt (Soliman \& Wahba, 2019). This article examines the five HRM practices for their key role in organisational success. For instance, selection and hiring processes represent an important stage for choosing the best workers who fit into the organisation and to the required tasks (Przytuła et al., 2020). On the other hand, training and development is essential to keep the task force equipped with the latest skills and knowledge required to perform their jobs (Karim, Choudhury, \& Latif, 2019). Additionally, the job design plays an important role in inspiring employees and decreasing turnover rates (Oldham \& Fried, 2016). Moreover, job security is essential for giving employees feelings of stability, which in turn will have a positive impact on their willingness to stay at their jobs (Reina et al., 2018). Job security is becoming very important for employees especially after the outbreak of COVID-19 pandemic, where many companies started aggressive layoff strategies for the purpose of cost reduction (Restubog, Ocampo, \& Wang, 2020).

Finally, the last HRM practice involves an effective reward and payment system which is considered one of the main factors that enhance employees' satisfaction and commitment (Aust, Matthews, \& Muller-Camen, 2020). By examining the impact of these five HRM practices on employee engagement, the present article can provide important guidelines for practitioners to follow to enhance the level of engagement of their workforce by applying effective HRM practices.

Another purpose of the current study is to examine the role of implementation of the organisational strategy on moderating the relationship between HRM practices and employee engagement. This is considered important because it is critical for all employees to clearly understand the mission and strategies of the organisations that they are working in (Osborne \& Hammoud, 2017). The extant literature shows that when employees understand the overall strategies of their organisations, they are more likely to be satisfied and loyal (Groen, Wouters, \& Wilderom, 2017).

This article is organised as follows: firstly, a literature review about the concepts of human resource practices and employee engagement is introduced. The literature review section further discusses the proposed conceptual framework together with the research hypotheses. Following this, the methodology that was adopted to collect and analyse the data is presented. Then the results and discussion of key findings are introduced. Finally, the contributions, limitations and scope of further research are presented.

\section{Literature review The concept of employee engagement}

The first formal definition for personnel engagement was provided by Kahn (1990). This definition considered it as the harnessing of organization members' selves to their work roles; in engagement, people employ and express themselves physically, cognitively, and emotionally during role performances (Kahn, 1990, p. 694).

Likewise, Saks (2019) argued that engaged employees have high sense of responsibility, where they feel that they should enhance their performance for the sake of their organisations. Thus, engaged employees generally possess high levels of involvement and commitment towards their organisations and values (Anitha, 2014). Therefore, it is critical for organisations to enhance the level of engagement of their employees, where engaged employees are enthusiastic about their work, where they put their maximum efforts for their organisations' interests and reputation (Sun \& Bunchapattanasakda, 2019). In contrast, disengaged employees usually escape from doing their work tasks, where they are generally passive and would cause damaging effects to their organisations' performance (Bhebhe, 2020).

The extant literature proposes three dimensions of employee engagement, which are cognitive, emotional and behavioural. These dimensions were first proposed by Kahn (1990) when he argued that engaged employees should possess the three forms of engagement to achieve superior performance in the workplace. 
Ashforth and Humphery (1995) supported this view by indicating that an engaged employee uses his or her 'hands, head and heart' when performing any task at work. These three dimensions were further examined in many later research studies that aimed at examining the nature of employee engagement in different organisations (Bakker, 2017; Budhiraja \& Yadav, 2020; Macey \& Schneider, 2008).

In the current study, we examine the impact of HRM practices on the cognitive, emotional and behavioural dimensions of employee engagement. Cognitive engagement refers to the degree to which employees concentrate and focus on their tasks, where they are mentally engaged and absorbed in achieving the mission of their organisations (Schuck \& Wollard, 2013). Joo et al. (2017) argued that the CE is one of the main factors that enhance the psychological well-being and happiness of employees. Thus, it is very critical for organisations to search for innovative ways that enhance the CE of their workers (Lauring \& Selmer, 2015). On the other hand, EE refers to the degree to which employees have positive affection towards their tasks and their organisations. It is linked to the emotions that affect employees' attitudes, whether negative or positive, towards the organisation and its top managers (Alhozi, Hawamdeh, \& Al-Edenat, 2021). Employees' positive emotional experiences, as well as their relationship with their colleagues, would form meaningful connections with the organisation (Luthans \& Peterson, 2002). The role of EE in enhancing the work performance has been highlighted in many articles in the field of organisational behaviour. For instance, Reina et al. (2018) argued that EE plays a critical role in decreasing the turnover rates in organisations, where employees' emotions towards their managers and their workplaces have a key role in their satisfaction at work. Finally, the behavioural dimension of engagement can be considered the physical representation of the cognitive and emotional dimensions. It can be recognised by observing employees' behaviours in the workplace (Park \& Tran, 2018). These behaviours can include commitment to finishing tasks on time, being proactive and active team leaders (Amin, Ghazali, \& Hassan, 2020).

Behaviourally engaged employees tend to exert the highest possible efforts at work, where they are committed to the achievement of their organisational missions (Shuck et al., 2017).

\section{The role of human resource management practices in enhancing employee engagement}

The extant literature underscores the importance of human capital in achieving superior performance and sustainability for organisations (Diaz-Carrion et al., 2021). This is in line with the view of strategic human resources scholars who argued that HRM practices can be a source of sustainable competitive advantage (Bogićević-Milikić, 2019; Boxall, 2018). This view has been proven empirically in numerous research studies that examined the relationship between various HRM practices and various firm-level outcomes (Boxall, 2018).
For these reasons, many companies across various business sectors have been eager to improve their HRM practices for the sake of enhancing their long-term profitability, employees' commitment and engagement (Otoo, 2019).

The relationship between various HRM practices and employee engagement has been studied in a number of academic publications (Ashill \& Rod, 2011; Presbitero, 2017; Yeh, 2013). For example, Rathnaweera (2010) argued that a number of HRM practices are needed to enhance the level of engagement. These practices include proper selection and hiring policies, adequate training and development of the task force as well as effective job design that is able to match the skills of employees to the required tasks. Van Zyl, Van Eeden and Rothmann (2013) further highlighted the role of job security programmes that tend to eliminate the fears of employees from losing their jobs.

In the current article, we focus on five HRM practices as we argue that these practices are essential in enhancing employee engagement. The first HRM practice that is examined in this study is the selection and hiring. This involves the recruitment of the best candidates who fit to the job requirements (Villegas, Lloyd, Tritt, \& Vengrouskie, 2019).

The literature shows some positive outcomes for the fairness in the selection and hiring process. For instance, Adam, Ogolla and Maore (2017) indicated that attracting and appointing qualified personnel is one of the most influential HRM practices that predict organisations' performance and profitability. Another HRM practice that is relevant to our study is the training and development. This practice involves providing employees with continuous training that allows them to perform their jobs in an effective and efficient manner (Karim et al., 2019). It also includes providing opportunities for self-development and career progress (Bibi, Ahmad, \& Majid, 2018).

Fletcher, Alfes and Robinson (2018) found that effective training and development will lead to better employee attitude and retention. The third HRM practice that is examined in our study is the job design. It involves designing work in an interesting way that inspires employees. Also, effective job design includes giving the employees flexibility to do the job in their own ways as long as they are doing it right (Oldham \& Fried, 2016). Ho and Wo (2019) argued that job design is a significant predictor of employees' motivation and excellent service quality.

Furthermore, our study proposes that job security can be an antecedent of employee engagement. Job security refers to the degree that employees feel that their organisations will keep them working as long as they are able to perform their tasks. Job security is a relevant HRM practice in our study because our study is conducted in Egypt, where individuals have high degree of risk avoidance and tend to look for stability (Badran \& Youssef-Morgan, 2015). In particular, after the outbreak of COVID-19 pandemic, the importance of 
job security has risen, where many organisations across different sectors tended to use downsizing strategies in order to survive during the pandemic (Wilson et al., 2020). Job insecurity is considered a major threat to employees because it gives employees a high sense of instability and stress, which negatively impacts their performance (Stander \& Rothmann, 2010). The final HRM practice that is examined in our study is the rewards and payment system. Crawford et al. (2014) argued that rewards and recognition are crucial and beneficial for employee engagement. Thus, it is very essential for companies to ensure that employees are rewarded based on their performance and that they feel that the organisations provide a fair rewarding and compensation system. From the previous discussions, we present the following hypotheses:

H1: Human resource management practices have a significant influence on employees' cognitive engagement.

H2: Human resource management practices have a significant influence on employees' emotional engagement.

H3: Human resource management practices have a significant influence on employees' behavioural engagement (BE).

\section{The moderating role of strategic implementation}

The extant literature highlights the importance of strategic implementation in enhancing the effectiveness of HRM practices. For instance, Barrick et al. (2015) indicated that for HRM practices to be properly executed in organisations, there should be strong support from top management to these practices. Strategic implementation refers to top managements' willingness to execute a clear strategy that has specific strategic objectives, and to use well-defined metrics to monitor and measure the achievement of these objectives (Barrick et al., 2015). In order to achieve this, everyone in the organisation should clearly understand the strategic goals and management goals should be built on the strategic priorities of the organisation (Hitt \& Ireland, 2017).

Furthermore, the management should get continuous feedback from the organisational stakeholders (Barrick et al., 2015).

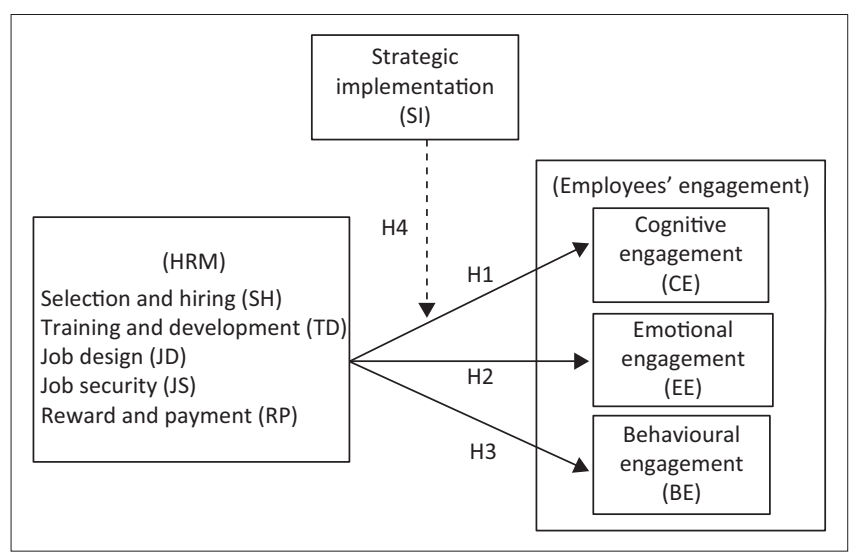

HRM, human resource management.

FIGURE 1: Proposed conceptual model.
In the current study, we propose a moderating role for strategic implementation on the relationship between HRM practices and employee engagement, where the literature shows the critical role of top management's support for formulating, and implementation of the strategy on HRM practices (Vance, 2006). For instance, Ho, $\mathrm{Wu}$ and $\mathrm{Wu}$ (2014) highlighted the role of top management's strategic implementation in fostering the organisations' ability to utilise their resources effectively and efficiently. From these discussions, we conclude the following hypothesis:

H4: Strategic implementation moderates the relationship between HRM practices and employee engagement.

In summary, Figure 1 shows the proposed conceptual model and research hypotheses.

\section{Methodology}

The current study followed a quantitative research approach by adopting the survey method. The target population of this study was employees from the banking sector in Egypt. The banking sector was chosen to study the impact of HRM practices on employee engagement for several reasons. Firstly, the banking sector is considered one of the strongest economic sectors that have contributed to the development of the Egyptian economy over the past few years (Shared, 2019). Another reason is the wide adoption of HRM practices in the Egyptian banks (Zaky \& Soliman, 2017), which represent the main construct in our study. From the purpose of the data collection, a link of an online survey was posted on the LinkedIn profiles of employees who work in a number of private and public banks in Egypt. After a period of 2 months, the researchers were able to get 228 complete questionnaires. The collected data were analysed using the Statistical Package for the Social Sciences (IBM SPSS Statistics 25).

The questionnaire was designed based on previously validated scales, where the researchers used a five-item Likert scale ranging from strongly disagree to strongly agree. To measure selection and hiring, five items were adapted from Rathnaweera (2010). To measure training and development, four items were adapted from a study by Lee and Bruvold (2015). To measure job design, four items were adapted from Rathnaweera (2010). To measure job security, four items were adapted from Van Zyl et al. (2013). To measure rewards and payment, four items were adapted from Barrick et al. (2015). On the other hand, 10 items were adapted from Purcell (2010) to measure CE and EE. Five items were further adapted from Shuck and Reio (2014) to measure the BE. Finally, six items were adapted from Barrick et al. (2015) to measure the strategic implementation. The items of the questionnaire are displayed in Table 1.

\section{Ethical considerations}

This article followed all ethical standards for a research without direct contact with human or animal subjects. 
TABLE 1: Items of the questionnaire.

\begin{tabular}{|c|c|}
\hline Construct & Items \\
\hline \multirow[t]{5}{*}{$\begin{array}{l}\text { HRM practice } 1 \\
\text { (Selection and hiring) }\end{array}$} & $\begin{array}{l}\text { Our recruitment system focuses on hiring the best } \\
\text { candidates. }\end{array}$ \\
\hline & $\begin{array}{l}\text { It's important to our organisation to choose } \\
\text { employees who fit to its strategic objectives. }\end{array}$ \\
\hline & $\begin{array}{l}\text { I think that my organisation is effective in matching } \\
\text { employees to its operational requirements. }\end{array}$ \\
\hline & $\begin{array}{l}\text { Selecting workers in our organisation does not depend } \\
\text { on favouritism. }\end{array}$ \\
\hline & $\begin{array}{l}\text { The recruitment system in our organisation focuses on } \\
\text { employees' skills and qualifications. }\end{array}$ \\
\hline \multirow[t]{4}{*}{$\begin{array}{l}\text { HRM practice } 2 \text { (Training } \\
\text { and development) }\end{array}$} & $\begin{array}{l}\text { My organisation focuses on the career development of } \\
\text { its employees. }\end{array}$ \\
\hline & $\begin{array}{l}\text { Career planning assistance is offered in our } \\
\text { organisation. }\end{array}$ \\
\hline & $\begin{array}{l}\text { My organisation offers ongoing training for its } \\
\text { employees. }\end{array}$ \\
\hline & $\begin{array}{l}\text { We are updated about job openings inside the } \\
\text { organisation. }\end{array}$ \\
\hline \multirow[t]{4}{*}{ HRM practice 3 (Job design) } & $\begin{array}{l}\text { The jobs inside the organisation are designed to be } \\
\text { inspiring. }\end{array}$ \\
\hline & I am interested in the job I do. \\
\hline & $\begin{array}{l}\text { I have the complete freedom in doing the job in the } \\
\text { way I think is right. }\end{array}$ \\
\hline & The organisation offers me flexibility in doing the job. \\
\hline \multirow[t]{4}{*}{ HRM practice 4 (Job security) } & $\begin{array}{l}\text { Providing employment security is important to our } \\
\text { organisation. }\end{array}$ \\
\hline & $\begin{array}{l}\text { We will stay in our jobs as long as we do it in a right } \\
\text { manner. }\end{array}$ \\
\hline & $\begin{array}{l}\text { I think I will work in the same organisation for many } \\
\text { years. }\end{array}$ \\
\hline & I am not worried about quitting my job. \\
\hline \multirow[t]{4}{*}{$\begin{array}{l}\text { HRM practice } 5 \text { (Rewards } \\
\text { and payments) }\end{array}$} & $\begin{array}{l}\text { The organisation rewards its employees based on their } \\
\text { effort and performance. }\end{array}$ \\
\hline & $\begin{array}{l}\text { Payments and bonuses are based on the effectiveness } \\
\text { of the employees. }\end{array}$ \\
\hline & $\begin{array}{l}\text { I think that the organisation pays us fair salaries if } \\
\text { compared to other organisations. }\end{array}$ \\
\hline & I think that the payment system in the organisation is fair. \\
\hline \multirow[t]{5}{*}{ Cognitive engagement } & I feel that my work is important to the organisation. \\
\hline & $\begin{array}{l}\text { I am focused on the work when I am in the } \\
\text { organisation. }\end{array}$ \\
\hline & $\begin{array}{l}\text { During the work hours, I usually concentrate on the } \\
\text { tasks I am doing. }\end{array}$ \\
\hline & $\begin{array}{l}\text { I have capabilities and resources to do the required } \\
\text { tasks. }\end{array}$ \\
\hline & $\begin{array}{l}\text { I am absorbed in doing the tasks that are assigned } \\
\text { to me. }\end{array}$ \\
\hline \multirow[t]{5}{*}{ Emotional engagement } & I feel a strong emotional bond with the organisation. \\
\hline & I feel proud to work for this organisation. \\
\hline & I have a strong sense of belonging to my organisation. \\
\hline & I am excited to do the required tasks. \\
\hline & I have positive attitudes towards my organisation. \\
\hline \multirow[t]{5}{*}{ Behavioural engagement } & I put the best of my knowledge in my job. \\
\hline & $\begin{array}{l}\text { I work very hard to achieve the tasks that are required } \\
\text { from me. }\end{array}$ \\
\hline & I work with my full power in my organisation. \\
\hline & I put much effort in my job. \\
\hline & I feel energetic whilst doing my job. \\
\hline \multirow[t]{6}{*}{ Strategic implementation } & $\begin{array}{l}\text { Our top management explains the strategic goals } \\
\text { clearly to all employees. }\end{array}$ \\
\hline & $\begin{array}{l}\text { We have clearly defined metrics that show the } \\
\text { progress of our work. }\end{array}$ \\
\hline & $\begin{array}{l}\text { The objectives of our teams are aligned with the } \\
\text { objectives of the organisation. }\end{array}$ \\
\hline & $\begin{array}{l}\text { The management gets feedback from all stakeholders } \\
\text { about the performance of the organisation. }\end{array}$ \\
\hline & $\begin{array}{l}\text { Our top management seeks timely feedback from all } \\
\text { employees about how well the organisational } \\
\text { strategies are achieved. }\end{array}$ \\
\hline & $\begin{array}{l}\text { The organisation regularly monitors the achievement } \\
\text { of the strategic objectives. }\end{array}$ \\
\hline
\end{tabular}

HRM, human resource management.

\section{Results Demographic statistics}

The analysis started by examining the descriptive statistics of the sample. The findings showed that out of the 228 respondents, $153(67 \%)$ were men, whilst 75 (33\%) were women. Also, the results indicated that 131 (57.4\%) of the respondents worked in private banks, whilst 97 (42.54\%) worked in public banks. Furthermore, the analysis showed that the majority of the respondents $(183 ; 80.26 \%)$ have experience more than 10 years in the banking sector, whilst 45 respondents (19.74\%) have less than 10 years of experience in the banking sector. Finally, the analysis showed that $115(50.43 \%)$ of the respondents worked in Cairo (the capital of Egypt), 84 (36.84\%) worked in Alexandria, whilst 28 (12.28\%) lived in other cities.

\section{Reliability analysis}

Ensuring the reliability of the study's constructs is important before testing the research hypotheses. Thus, the analysis showed that all the study constructs possess strong reliability, with a Cronbach's alpha value above the recommended threshold of 0.7 (Bryman \& Bell, 2015). Table 2 demonstrates Cronbach's alpha values of the study constructs.

\section{Regression analysis for hypotheses testing}

H1: Human resource management practices have a significant influence on employees' cognitive engagement. (Supported)

As shown in Table 3, hypothesis 1 was supported, where the findings showed a significant effect of HRM practices on CE $(\beta=0.564, p=0.000)$. Table 2 also indicates that $R$ square $=$ 0.318 , which indicates that $31.8 \%$ of the change in $C E$ is predicted by the five HRM practices, which are selection and hiring, training and development, job design, job security, and rewards and payment:

H2: Human resource management practices have a significant influence on employees' emotional engagement. (Supported)

As displayed in Table 4, hypothesis 2 was supported, where the findings indicated a significant influence of HRM practices on EE $(\beta=0.666, p=0.000)$. Furthermore, Table 3 shows that $R$ square $=0.443$, which indicates that $44.3 \%$ of the change in EE is predicted by the five HRM practices, which are selection and hiring, training and

TABLE 2: Cronbach's alpha values of the study constructs.

\begin{tabular}{lcc}
\hline Variables & Cronbach's alpha & Number of items \\
\hline Selecting and hiring & 0.872 & 5 \\
Training and development & 0.880 & 4 \\
Job design & 0.783 & 4 \\
Job security & 0.734 & 4 \\
Rewards and payment & 0.861 & 4 \\
Strategic implementation & 0.938 & 6 \\
Employee' cognitive engagement & 0.842 & 5 \\
Employee' emotional engagement & 0.914 & 5 \\
Employee' behavioural engagement & 0.924 & 5 \\
\hline
\end{tabular}


development, job design, job security, and rewards and payments:

H3: Human resource management practices have a significant influence on employees' behavioural engagement. (Supported)

As shown in Table 5, it was found that HRM practices have a positive significant impact on $\mathrm{BE}(\beta=0.483$, $p=0.000)$. On the other hand, $R$ square $=0.233$, which indicates that $23.3 \%$ of the change in $\mathrm{BE}$ is predicted by the five HRM practices, which include selection and hiring, training and development, job design, job security, and rewards and payment:

H4: Strategic implementation moderates the relationship between HRM practices and employee engagement. (Rejected)

TABLE 3a: Model summary for the predictors of cognitive engagement.

\begin{tabular}{lcccc}
\hline Model & $\boldsymbol{R}$ & $\boldsymbol{R}$ square & $\begin{array}{c}\text { Adjusted } \boldsymbol{R} \\
\text { square }\end{array}$ & Std. error of the estimate \\
\hline Model Summary & & & \\
1 & $0.564^{\mathrm{a}}$ & 0.318 & 0.303 & 0.624 \\
\hline
\end{tabular}

a, Predictors: (Constant), HRM practices.

TABLE 3b: Model summary for the predictors of cognitive engagement.

\begin{tabular}{llccccc}
\hline Model & & $\begin{array}{c}\text { Sum of } \\
\text { squares }\end{array}$ & $d f$ & $\begin{array}{c}\text { Mean } \\
\text { square }\end{array}$ & $\boldsymbol{F}$ & Sig. \\
\hline ANOVA $^{\text {a }}$ & & & & & & \\
1 & Regression & 39.975 & 5 & 7.995 & 20.528 & $0.000^{\mathrm{b}}$ \\
& Residual & 85.682 & 220 & 0.389 & - & - \\
& Total & 125.656 & 225 & - & - & - \\
\hline
\end{tabular}

a, Dependent variable: CE; b, Predictors: (Constant), HRM practices.

TABLE 4a: Model summary of the predictors of emotional engagement.

\begin{tabular}{lrrrr}
\hline Model & $\boldsymbol{R}$ & $\boldsymbol{R}$ square & $\begin{array}{c}\text { Adjusted } \boldsymbol{R} \\
\text { square }\end{array}$ & Std. error of the estimate \\
\hline Model Summary & & & \\
1 & $0.666^{\mathrm{a}}$ & 0.443 & 0.431 & 0.709 \\
\hline
\end{tabular}

a, Predictors: (Constant), HRM practices.

\begin{tabular}{llccccc}
\multicolumn{2}{l}{ TABLE 4b: Model summary of the predictors of emotional engagement. } \\
\hline Model & & $\begin{array}{c}\text { Sum of } \\
\text { squares }\end{array}$ & $d f$ & $\begin{array}{c}\text { Mean } \\
\text { square }\end{array}$ & $\boldsymbol{F}$ & Sig. \\
\hline ANOVA $^{\text {a }}$ & & & & & & \\
1 & Regression & 88.020 & 5 & 17.604 & 35.061 & $0.000^{\text {b }}$ \\
& Residual & 110.461 & 220 & 0.502 & - & - \\
& Total & 198.481 & 225 & - & - & - \\
\hline
\end{tabular}

a, Dependent Variable: EE; b, Predictors: (Constant), HRM practices.

TABLE 5a: Model summary of the predictors of behavioural engagement.

\begin{tabular}{lcccc}
\hline Model & $\boldsymbol{R}$ & $\boldsymbol{R}$ square & $\begin{array}{c}\text { Adjusted } \boldsymbol{R} \\
\text { square }\end{array}$ & Std. error of the estimate \\
\hline Model Summary & & & \\
1 & $0.483^{\mathrm{a}}$ & 0.233 & 0.216 & 0.722 \\
\hline
\end{tabular}

a, Predictors: (Constant), HRM practices.

\begin{tabular}{llccccc}
\multicolumn{2}{l}{ TABLE 5b: Model summary of the predictors of behavioural engagement. } \\
\hline Model & & $\begin{array}{c}\text { Sum of } \\
\text { squares }\end{array}$ & $\boldsymbol{d f}$ & $\begin{array}{c}\text { Mean } \\
\text { square }\end{array}$ & $\boldsymbol{F}$ & Sig. \\
\hline ANOVA $^{\text {a }}$ & & & & & & \\
1 & Regression & 34.894 & 5 & 6.979 & 13.403 & $0.000^{\mathrm{b}}$ \\
& Residual & 114.555 & 220 & 0.521 & - & - \\
& Total & 149.449 & 225 & - & - & - \\
\hline
\end{tabular}

a: Dependent Variable: BE; b: Predictors: (Constant), HRM practices.
There are two models in this analysis. Model 1 shows the relationship between HRM practices, strategic implementation and employee engagement. The model is significant where $\beta=0.632$ and $p=0.001$. On the other hand, model 2 involves testing the moderating effect of the strategic implementation on the relationship between HRM practices and employee engagement. The model is significant as $p=0.01$, whilst $\beta=0.632$. The $R$ square is 0.399 , which indicates that $39.9 \%$ of the change in the dependent variable is predicted by the independent variables. The result of the coefficients table is that model 1 is significant but model 2 is not because the moderator effect of (CenSI*CenHRM) has a $p$-value equal to 0.990 , which is greater than 0.05 . Hence, hypothesis 4 is rejected.

\section{Discussion}

The findings underscore the importance of HRM practices in enhancing the emotional, cognitive and behavioural dimensions of employee engagement. In particular, the article highlights the role of five important HRM practices which are selection and hiring, training and development, job design, job security, and rewards and payment. These findings are in line with the findings of some articles that showed the critical importance of HRM practices in enhancing employee engagement. For instance, Aktar and Pangil (2017) indicated that a variety of HRM practices, such as the job security and career development, are important to enhance the level of engagement. These findings have also been confirmed in the work of Jose (2012), which indicated that the level of employee engagement is determined by the level of satisfaction with the human resource practices.

Our findings provide an important contribution to the literature about employee engagement. For instance, the findings showed the importance of selection and hiring in enhancing the level of engagement. This view was supported in the literature, which indicated that the recruitment process plays an important role in predicting employees' active engagement in the workplace (Bhutta \& Zafar, 2019). Additionally, our findings highlighted the role of training and development in enhancing employee engagement. These findings have been supported by the work of Mansour (2020) which showed that the level of employee engagement depends on the training that employees get access to in the workplace. Another interesting finding of this article is the importance of job security in enhancing engagement levels of employees. This result finds much support in several empirical studies which indicated that employees' perceptions of insecurity in the workplace will lead to poor performance and high levels of disengagement (Chen, 2018; Ugwu \& Okojie, 2016). The importance of providing job security to employees has grown in importance, especially after the COVID-19 pandemic (Wilson et al., 2020). Our article shows the importance of providing job security, especially in counties like Egypt, where employees are generally looking for stability, where Egyptians, in general, are less likely to change their jobs and companies (Soliman \& Wahba, 2019). 
Our findings further underscore the importance of job design and reward systems in improving employee engagement. These findings are consistent with that of Tims and Bakker (2014), which showed that well-designed jobs can be inspiring for employees and can largely contribute to their level of engagement. Also, they are consistent with the findings of Waqas and Saleem (2014) that highlighted the role of monetary and non-monetary rewards in increasing the level of employee engagement and performance of organisations. However, our findings showed that strategic implementation does not moderate the relationship between HRM practices and employee engagement. This might be attributed to the lack of knowledge that employees have about the strategies and objectives of the Egyptian banks. These findings are not in line with the findings of Barrick et al. (2015) which showed that strategic implementation plays an important role in increasing employees' performance and productivity. Thus, it is apparent that the majority of Egyptian banks have been unsuccessful in explaining their strategies to employees.

\section{Implications to theory and practice}

This article responds to several calls from management scholars for studying the factors that enhance employee engagement (Bhutta \& Zafar, 2019; Jose, 2012). Through an empirical study by drawing a sample of employees from the banking sector in Egypt, this article was able to show the significant role of various HRM practices in enhancing employee engagement. Our study contributes by being one of the first studies that examine how HRM practices impact employee engagement in Egypt as an example of developing countries. Furthermore, the current study contributes by examining the three dimensions of employee engagement that were proposed by Shuck et al. (2017). This is considered important, where investigating the different facets of engagement provides a detailed explanation of the relatively new concept in the field of organisational behaviour studies.

Our study also provides some important guidelines for HR managers in the banking sector to follow in order to be able to enhance employee engagement. Firstly, organisations should ensure that they have effective hiring and selection policies. By doing this, they will be able to attract the best candidates that fit to the organisational culture. Another importance of this practice lies in the fact that when employees perceive that selection and hiring is conducted fairly, they will feel that their organisations apply fair HRM practices, which subsequently enhances their engagement. Also, organisations should not neglect the importance of continuous training and development of their staff. This is becoming very important with the new technological innovations that are introduced in the banking sector. Effective training that equips employees with relevant skills can make them more satisfied whilst doing their daily tasks. Another important HRM practice that should be developed is the job design. This could be conducted by designing jobs in a way that is flexible and decentralised, where employees should be given more freedom to do their tasks in their own way as long as they are doing it right. Furthermore, organisations should increase the perception of the job security by their employees, especially in countries like Egypt, where employees tend to have high risk avoidance. This HRM practice is becoming more important with the outbreak of COVID-19 pandemic, where many employees have high fears to be forced to leave their jobs. Also, organisations should provide fair compensation and reward systems that are based on performance. This is critical, where the findings showed the importance of this HRM practice in enhancing employee engagement. Finally, organisations should make sure to focus on internal marketing practices that ensure the alignment of all employees to the strategic objectives. This can be conducted by providing awareness sessions to employees about the mission statements, strategic objectives and key performance indicators of their organisations.

\section{Research limitations and directions for future research}

Despite the fact that this article provides important contributions to theory and practice, it has some limitations. Firstly, the article only examined the impact of five HRM practices on employee engagement. Future studies can further examine some other important HRM practices, such as the quality of work environment and work safety. Another limitation of our study is that it only examined employees working in one industry, that is, the banking sector in Egypt. Future studies can draw samples from other industries in different countries, where they can investigate how culture can impact the acceptance of HRM practices. Also, future studies can investigate each of the HRM practices separately to be able to provide a comparison of the impact of each of them on employee engagement. Furthermore, future studies can adopt qualitative approaches, which will provide an in-depth understanding of the factors that enhance employee engagement. Finally, further research is needed to examine how internal marketing practices influence employee engagement, especially in developing countries like Egypt.

\section{Acknowledgements Competing interests}

The authors have declared that no competing interest exists.

\section{Authors' contributions}

This article was written by a team of researchers from the Arab Academy for Science, Technology and Maritime Transport. M.M.S. had a key role in data collection, data analysis and writing the first draft of the article. H.G. and A.L. had key roles in revising the article and responding to reviewers' comments.

\section{Funding information}

This research received no specific grant from any funding agency in the public, commercial or not-for-profit sectors. 


\section{Data availability}

Data are available within the article or its supplementary materials, and other data are available from the authors upon reasonable request.

\section{Disclaimer}

The views and opinions expressed in this article are those of the authors and do not necessarily reflect the official policy or position of any affiliated agency of the authors.

\section{References}

Adam, O.A.S., Ogolla, D., \& Maore, S. (2017). Influence of human resource hiring practices on performance of United Nations agencies in Mogadishu, Somalia. International Academic Journal of Human Resource and Business Administration, 2(3), 677-701.

Aktar, A., \& Pangil, F. (2017). The relationship between employee engagement, HRM practices and perceived organizational support: Evidence from banking employees. International Journal of Human Resource Studies, 7(3), 1-22. https:// doi.org/10.5296/ijhrs.v7i3.11353

Alhozi, N., Hawamdeh, N.A., \& Al-Edenat, M. (2021). The impact of employee empowerment on job engagement: Evidence from Jordan. International Business Research, 14(2), 1-90. https://doi.org/10.5539/ibr.v14n2p90

Amin, M., Ghazali, Z., \& Hassan, R. (2020). A conceptual model: Frontline employee's behavioral engagement in value co-creation. Humanities \& Social Sciences Reviews, 8(2), 474-481. https://doi.org/10.18510/hssr.2020.8254

Anitha, J. (2014). Determinants of employee engagement and their impact on employee performance. International Journal of Productivity and Performance Management, 63(3), 308-323. https://doi.org/10.1108/IJPPM-01-2013-0008

Ashforth, B.E., \& Humphrey, R.H. (1995). Emotion in the workplace: A reappraisal. Human relations, 48(2), 97-125.

Ashill, N.J., \& Rod, M. (2011). Burnout processes in non-clinical health service encounters. Journal of Business Research, 64(10), 1116-1127.

Aust, I., Matthews, B., \& Muller-Camen, M. (2020). Common good HRM: A paradigm shift in sustainable HRM? Human Resource Management Review, 30(3), 100705. https://doi.org/10.1016/j.hrmr.2019.100705

Badran, M.A., \& Youssef-Morgan, C.M. (2015). Psychological capital and job satisfaction in Egypt. Journal of Managerial Psychology, 30(3), 354. https://doi. org/10.1108/JMP-06-2013-0176

Bakker, A.B. (2017). Strategic and proactive approaches to work engagement. Organizational Dynamics, 46(2), 67-75. https://doi.org/10.1016/j. orgdyn.2017.04.002

Barrick, M.R., Thurgood, G.R., Smith, T.A., \& Courtright, S.H. (2015). Collective organizational engagement: Linking motivational antecedents, strategic implementation, and firm performance. Academy of Management Journal, 58(1) 111-135. https://doi.org/10.5465/amj.2013.0227

Bhebhe, M. (2020). Employee disengagement from the perspective of frontline employees: A hotel case study in Zimbabwe. Journal of Management \& Administration, 2020(1), 73-100.

Bhutta, Z.M., \& Zafar, S. (2019). Impact of HRM practices on employee engagement: Evidence from banking sector of Pakistan. NUML International Journal of Busines \& Management, 14(2), 140-156. https://doi.org/10.26573/2020.14.2.4

Bibi, P., Ahmad, A., \& Majid, A.H.A. (2018). The impact of training and development and supervisor support on employee's retention in academic institutions: The moderating role of work environment. Gadjah Mada International Journal of Business, 20(1), 113-131. https://doi.org/10.22146/gamaijb.24020

Bogićević-Milikić, B. (2019). Promoting gender-responsive talent management in police organizations through strategic HRM measuring. Strategic Management 24(1), 19-29. https://doi.org/10.5937/StraMan1901019B

Boxall, P. (2018). The development of strategic HRM: Reflections on a 30-year journey. Labour \& Industry: A Journal of the Social and Economic Relations of Work, 28(1) 21-30. https://doi.org/10.1080/10301763.2018.1427423

Bryman, A., \& Bell, E. (2015). Business research methods. New York: Oxford University Press.

Budhiraja, S., \& Yadav, S. (2020) Employer Branding and Employee-Emotional Bonding - The CSR Way to Sustainable HRM. In S. Vanka, M.B. Rao, S. Singh, M.R. Pulaparthi (Eds.) Sustainable Human Resource Management. Singapore: Springer. https://doi.org/10.1007/978-981-15-5656-2 \&

Chen, S.L. (2018). Cross-level effects of high-commitment work systems on work engagement: The mediating role of psychological capital. Asia Pacific Journal of Human Resources, 56(3), 384-401. https://doi.org/10.1111/1744-7941.12144

Crawford, E.R., Rich, B.L., Buckman, B., \& Bergeron, J. (2014). The antecedents and drivers of employee engagement. Employee engagement in theory and practice, 44(6), 57-81.

Deeb, A., Alananzeh, O.A., Tarhini, A., \& Masa'deh, R.E. (2020). Factors affecting job performance: the case of Jordanian hotels' kitchen staff. International Journal of Public Sector Performance Management, 6(3), 340-360.
Diaz-Carrion, R., López-Fernández, M., \& Romero-Fernandez, P.M. (2021). Constructing an index for comparing human resources management sustainability in Europe. Human Resource Management Journal, 31(1), 120-142. https://doi. org/10.1111/1748-8583.12286

Fletcher, L., Alfes, K., \& Robinson, D. (2018). The relationship between perceived training and development and employee retention: The mediating role of work attitudes. The International Journal of Human Resource Management, 29(18), 2701-2728. https://doi.org/10.1080/09585192.2016.1262888

Groen, B.A., Wouters, M.J., \& Wilderom, C.P. (2017). Employee participation, performance metrics, and job performance: A survey study based on selfdetermination theory. Management Accounting Research, 36, 51-66. https://doi. org/10.1016/j.mar.2016.10.001

Hitt, M., \& Ireland, R. (2017). The intersection of entrepreneurship and strategic management research. In L. Donald, Sexton Hans Landström (Ed.), The Blackwell handbook of entrepreneurship (pp. 45-63). New Jersey: Hoboken.

Ho, C.W., \& Wu, C.C. (2019). Using job design to motivate employees to improve highquality service in the airline industry. Journal of Air Transport Management, 77 17-23. https://doi.org/10.1016/j.jairtraman.2019.02.008

Ho, J.L., Wu, A., \& Wu, S.Y. (2014). Performance measures, consensus on strategy implementation, and performance: Evidence from the operational-level of organizations. Accounting, Organizations and Society, 39(1), 38-58. https://doi. org/10.1016/j.aos.2013.11.003

Joo, B.K., Zigarmi, D., Nimon, K., \& Shuck, B. (2017). Work cognition and psychological well-being: The role of cognitive engagement as a partial mediator. The Journal of Applied Behavioral Science, 53(4), 446-469. https://doi.org/10.1177/ 0021886316688780

Jose, G. (2012). Satisfaction with HR practices and employee engagement: A social exchange perspective. Journal of Economics and Behavioral Studies, 4(7) 423-430. https://doi.org/10.22610/jebs.v4i7.343

Kahn, W.A. (1990). Psychological conditions of personal engagement and disengagement at work. Academy of Management Journal, 33(4), 692-724. https://doi.org/10.2307/256287

Karim, M.M., Choudhury, M.M., \& Latif, W.B. (2019). The impact of training and development on employees' performance: An analysis of quantitative data. Noble International Journal of Business and Management Research, 3(2), 25-33.

Lauring, J., \& Selmer, J. (2015). Job engagement and work outcomes in a cognitively demanding context. Personnel Review, 44(4), 629-647. https://doi.org/10.1108/ PR-11-2013-0216

Lee, C.H., \& Bruvold, N.T. (2003). Creating value for employees: Investment in employee development. The International Journal of Human Resource Management, 14(6), 981-1000. https://doi.org/10.1080/0958519032000106173

Luthans, F., \& Peterson, S. (2002). Employee engagement and manager self-efficacy. Journal of Management Development, 21(5), 376-387. https://doi. org/10.1108/02621710210426864

Macey, W.H., \& Schneider, B. (2008). The meaning of employee engagement. Industrial and organizational Psychology, 1(1), 3-30. https://doi. Industrial and organizational Psyc
org/10.1111/j.1754-9434.2007.0002.x

Mansour, M. (2020). The relationship between human resources management practices and job engagement: The mediating role of psychological capital. Management Science Letters, 10(13), 3047-3056. https://doi.org/10.5267/j.msl.2020.5.019

Oldham, G.R., \& Fried, Y. (2016). Job design research and theory: Past, present and future. Organizational Behavior and Human Decision Processes, 136, 20-35. https://doi.org/10.1016/j.obhdp.2016.05.002

Osborne, S., \& Hammoud, M.S. (2017). Effective employee engagement in the workplace. International Journal of Applied Management and Technology, 16(1) 4. https://doi.org/10.5590/IJAMT.2017.16.1.04

Otoo, F.N.K. (2019). The mediating role of employee competencies. International Journal, 41(5), 949-970. https://doi.org/10.1108/ER-02-2018-0053

Park, J.H., \& Tran, T.B.H. (2018). Internal marketing, employee customer-oriented behaviors, and customer behavioral responses. Psychology \& Marketing, 35(6), 412-426. https://doi.org/10.1002/mar.21095

Presbitero, A. (2017). How do changes in human resource management practices influence employee engagement? A longitudinal study in a hotel chain in the Philippines. Journal of Human Resources in Hospitality \& Tourism, 16(1), 56-70.

Przytuła, S., Strzelec, G., \& Krysińska-Kościańska, K. (2020). Re-vision of future trends in human resource management (HRM) after COVID-19. Journal of Intercultura Management, 12(4), 70-90. https://doi.org/10.2478/joim-2020-0052

Purcell, J. (2010), Building Employee Engagement, ACAS Policy Discussion Paper, London: ACAS.

Rathnaweera, R.R.N.T. (2010). Do Hrm practices impact employee satisfaction, commitment or retention? An empirical study of Sri Lankan public sector banks. A master's dissertation of the University of Agder, Sri Lanka.

Reina, C.S., Rogers, K.M., Peterson, S.J., Byron, K., \& Hom, P.W. (2018). Quitting the boss? The role of manager influence tactics and employee emotional engagement in voluntary turnover. Journal of Leadership \& Organizational studies, 25(1), 5-18. in voluntary turnover. Journal of Leadership \&

Restubog, S.L.D., Ocampo, A.C.G., \& Wang, L. (2020). Taking control amidst the chaos: Emotion regulation during the COVID-19 pandemic. Journal of Vocational Behavior, 119, 103440. https://doi.org/10.1016/j.jvb.2020.103440

Saks, A.M. (2019). Antecedents and consequences of employee engagement revisited Journal of Organizational Effectiveness, 6(1), 19-38. https://doi.org/10.1108/ JOEPP-06-2018-0034

Shared, H.A. (2019). The relationship between e-service quality and e-customer satisfaction: An empirical study in Egyptian Banks. International Journal of
Business and Management, 14(5), 171. https://doi.org/10.5539/ijbm.v14n5p171 
Shuck, B., \& Reio, Jr. T.G. (2014). Employee engagement and well-being: A moderation model and implications for practice. Journal of Leadership \& Organizational Studies, 21(1), 43-58. https://doi.org/10.1177/1548051813494240

Shuck, B., Adelson, J.L., \& Reio. Jr. T.G. (2017). The employee engagement scale: Initial evidence for construct validity and implications for theory and practice. Human Resource Management, 56(6), 953-977. https://doi.org/10.1002/hrm.21811

Shuck, M.B., \& Wollard, K.K. (2009). A Historical Perspective of Employee Engagement: An Emerging Definition. COERC 2009, 133

Soliman, M., \& Wahba, M.S. (2019). Investigating influencers of employee engagement in travel agents in Egypt. Anatolia, 30(1), 75-89. https://doi.org/10.1080/130329 17.2018.1503965

Stander, M.W., \& Rothmann, S. (2010). Psychological empowerment, job insecurity and employee engagement. SA Journal of Industrial Psychology, 36(1), 1-8.

Sun, L., \& Bunchapattanasakda, C. (2019). Employee engagement: A literature review. International Journal of Human Resource Studies, 9(1), 63-80. https://dol. org/10.5296/ijhrs.v9i1.14167

Tims, M., \& Bakker, A.B. (2014). Job design and employee engagement. In C. Truss, R. Delbridge, K. Alfes, A. Shantz, \& E. Soane (Eds.), Employee engagement in theory and practice (pp. 131-148). Oxon: Taylor and Francis.

Ugwu, C.C., \& Okojie, J.O. (2016). Human resource management (HRM) practices and work engagement in Nigeria: The mediating role of psychological capital (PSYCAP). International Journal of Social Sciences and Humanities Review, 6(4), 71-87.
Vance, R.J. (2006). Employee engagement and commitment. In F.P. Morgeson (Ed.), Society for Human Resource Management (SHRM) (pp. 1-53). VA: Alexandria.

Van Zyl, L., Van Eeden, C., \& Rothmann, S. (2013). Job insecurity and the emotional and behavioural consequences thereof. South African Journal of Business Management, 44(1), 75-86. https://doi.org/10.4102/sajbm.v44i1.149

Villegas, S., Lloyd, R.A., Tritt, A., \& Vengrouskie, E.F. (2019). Human resources as ethical gatekeepers: Hiring ethics and employee selection. Journal of Leadership, Accountability and Ethics, 16(2), 80-88. https://doi.org/10.4102/ sajbm.v44i1.149

Waqas, Z., \& Saleem, S. (2014). The effect of monetary and non-monetary rewards on employee engagement and firm performance. European Journal of Business and Management, 6(31), 73-82

Wilson, J.M., Lee, J., Fitzgerald, H.N., Oosterhoff, B., Sevi, B., \& Shook, N.J. (2020). Job insecurity and financial concern during the COVID-19 pandemic are associated with worse mental health. Journal of Occupational and Environmental Medicine, 62(9), 686-691. https://doi.org/10.1097/JOM.0000000000001962

Yeh, C.M. (2013). Tourism involvement, work engagement and job satisfaction among frontline hotel employees. Annals of Tourism Research, 42, 214-239.

Zaky, A.H.M. \& Soliman, M.M. (2017). The effect of knowledge management critical success factors on knowledge management effectiveness and performance: An empirical research in Egyptian banking sector. The Business \& Management Review, 9(2), 201-211. 